\title{
ESTUDIO Y APLICACIONES DE PROPIEDADES ÓPTICAS, MAGNÉTICAS Y DE TRANSPORTE DE CARGA DE NANOCOMPUESTOS BASADOS EN MEMBRANAS POROSAS
}

Luisina Forzani

luisina.forzani@santafe-conicet.gov.ar

Doctorado en Física

Director: Roberto Román Koropecki

Co-directora: Ana María Gennaro

Lugar de trabajo: Laboratorio de física de semiconductores, Instituto de Física del Litoral.

Fecha de defensa: 25 de marzo de 2019

\section{RESUMEN}

Por Se estudiaron membranas de alúmina anódica porosa nanoestructurada (AAPN) y silicio poroso bajo las formas de silicio mesoporoso (SP) y macroporoso (SMP) usadas como matriz en nanocompuestos. Se montó una nueva línea de fabricación de AAPN en el laboratorio de Física de Semiconductores. Partiendo de un sustrato de aluminio de alta pureza fue posible obtener AAPN con un alto grado de ordenamiento. Los parámetros estructurales de la AAPN se caracterizaron a través de imágenes obtenidas por microscopía de fuerza atómica y electrónica de barrido. Además se determinó que la alúmina que conforma la matriz de AAPN es amorfa.

Mediante un tratamiento del sustrato de aluminio sobre el que crece la alúmina porosa, previo al anodizado, se ha logrado aumentar el tamaño de los granos cristalinos del aluminio hasta $5 \mathrm{~mm}$ o más. Se observó que el espesor físico de la alúmina porosa fabricada a partir de este aluminio pretratado está definido por la orientación cristalina del grano subyacente del sustrato sobre el que crece. De esta manera se delimitan zonas en la alúmina porosa, con dimensiones típicas del orden de los milímetros, cuyas propiedades ópticas fueron estudiadas. Se estudió y caracterizó la anisotropía óptica, es decir, la birrefringencia que presenta este material en las distintas zonas. Se encontró una correlación entre la orientación cristalina del sustrato, determinada mediante difracción de electrones retrodispersados, y la anisotropía óptica de la membrana de alúmina resultante.

A partir de películas de AAPN que conservan su sustrato de aluminio se fabricaron nanocompuestos introduciendo níquel dentro de los poros por una técnica de electrodeposición pulsada, y posteriormente removiendo el sustrato de aluminio. Estos nanocompuestos permitieron realizar estudios del comportamiento de la matriz de alúmina y de los nanohilos de Ni. En particular -y aprovechando la alineación que adoptan los nanohilos en el nanocompuesto- se estudió la anisotropía de las propiedades magnéticas y su variación con la temperatura. Por otro lado se realizaron experimentos de difracción de rayos $\mathrm{X}$ sobre los nanohilos embebidos en alúmina, que permitieron encontrar un comportamiento 
anómalo del coeficiente de expansión térmica del nanocompuesto que concuerda con los resultados del estudio magnético. En base a estos resultados se encontró que el coeficiente de expansión térmica de la matriz de alúmina es negativo en el rango de temperaturas estudiado. De los experimentos con DRX y los estudios magnéticos se concluye que existen efectos magnetoelásticos asociados a la variación de la temperatura del nanocompuesto.

Se diseñaron y fabricaron microcavidades ópticas híbridas a partir de membranas de AAPN y cristales fotónicos unidimensionales de silicio mesoporoso. Estos dispositivos sirven como plataforma para sensores químicos o biosensores basados en propiedades fotónicas, con gran sensibilidad en el rango de las bajas longitudes de onda. Se buscó rescatar las mejores características de cada material nanoestructurado, aprovechando el bajo coeficiente de absorción de la AANP y mayor contraste en los índices de refracción obtenibles con SP, de manera de lograr obtener cavidades con espesores físicos del orden de decenas de micrómetros con baja absorción en el espectro visible, proporcionando un alto factor de calidad Q y transmitancia relativamente alta. Esto permitiría una mayor versatilidad de respuesta en presencia de un analito específico.

Se preparó otro tipo de microcompuesto mediante el llenado de poros de silicio macroporoso con lípidos. A diferencia del SP, cuyos poros adoptan una forma dendrítica, el SMP presenta poros cilíndricos perpendiculares a la superficie de gran relación de aspecto y diámetro uniforme. Mediante espectroscopía de resonancia paramagnética electrónica (EPR) se estudió el comportamiento de los lípidos mediante la incorporación de marcadores de espín, verificando que una parte importante de los lípidos se organizan en bicapas lipídicas cilíndricas sobre las paredes de los poros. Este sistema puede ser considerado como una plataforma para el estudio, tanto por EPR como por métodos ópticos, de transiciones de fase termotrópicas de los lípidos en un entorno confinado.

\section{ABSTRACT}

\section{Study and applications of optical, magnetic and charge transport properties of composite na- nomaterials based on porous membranes}

Nanostructured porous anodic alumina membranes (NPAA) and porous silicon under the forms of mesoporous (PS) and macroporous (MPS) silicon were studied and used as matrices in nanocomposites. We deposited nickel into NPAA pores to produce nanocomposites of alumina and nickel nanowires. This system allowed the study of the behavior of the alumina matrix and nanowires. We studied the anisotropy of the magnetic properties and their variation with temperature. Through $\mathrm{X}$-ray diffraction experiments we found an anomalous behavior of the thermal expansion coefficient of the nano-composite that agrees with the magnetic results. On the other hand, hybrid optical microcavities were designed 
and manufactured from NPAA membranes and PS one-dimensional photonic crystals, using the best characteristics of each nanostructured material, achieving cavities with a high quality factor and relatively high transmittance. These devices serve as a platform for chemical sensors or biosensors based on photonic properties, with great sensitivity in the low wavelengths range. In addition, another type of micro-composite was studied by filling MPS pores with lipids. Using electron paramagnetic resonance spectroscopy, we studied the lipid behavior incorporating spin labels, verifying that an important part of the lipids are organized in cylindrical lipid bilayers forming nanotubes in the pore walls. This system can be considered as a platform for the study of thermotropic phase transitions of lipids in a confined environment. 